\title{
Pengaruh Nilai Pelanggan, Kepuasan Pelanggan dan Kepercayaan terhadap Loyalitas Pelanggan pada Kedai Kopi Online di Kota Medan
}

\author{
Stevani Korentia Sebayang \\ Fakultas Ekonomi dan Bisnis, Universitas Sumatera Utara \\ Syafrizal Helmi Situmorang \\ Fakultas Ekonomi dan Bisnis, Universitas Sumatera Utara \\ E-mail : stevani.sebayang13@gmail.com
}

\begin{abstract}
The purpose of this study was to determine the influence of perceived value, customer satisfaction, and trust on online coffee shop customer loyalty in medan city. The population in this study are customer of online coffee shops in the city of Medan. The sample in this study were 150 online coffee shop customer in city of Medan who had bought online coffee priducts at least 2 times. The method of analysis used in this research is descriptive analysis method and multiple linear regression analysis processed with SPSS for windows software. Based on the F test (simultaneously) it shows that customer value, customer satisfaction and trust together or simultaneously have a significant effect on customer loyalty. The results of $t-$ test (partial), the variable customer value has a positive and significant effect on customer loyalty, the customer satisfaction variable has a positive and significant effect on customer loyalty, and trust has a positive and significant effect on customer loyalty. Based on the large value of Adjusted Rsquare, it can be seen that the variable customer value, customer satisfaction and trust have a simultaneous effect on customer loyalty by 0.462 or $46.2 \%$ while the remaining $53.8 \%$ are other factors outside the variables studied.
\end{abstract}

Keywords : Perceived Value, Customer Satisfaction, Trust dan Customer Loyalty

\section{Pendahuluan}

Laporan Statistik Kopi Indonesia (2017) menyebutkan sub sektor perkebunan memiliki potensi yang cukup besar dengan menempati urutan pertama pada sektornya, yaitu sektor Pertanian, Peternakan, Perburuan dan Jasa Pertanian. Sub sektor pertanian juga penyedia bahan baku untuk sektor indrustri, penyerap tenaga kerja, dan penghasil devisa. Investasi pada sektor kopi yang dianggap peluang paling baik adalah para pelaku usaha mendirikan kedai kopi. Menurut Chairman Specialty Coffee Association of Indonesia (SCAI) Syafrudin, Pertumbuhan kedai kopi hingga akhir tahun 2019, mengalami peningkatan sebesar 15\% $20 \%$, bila dibandingkan tahun 2018 yang hanya mencapai $8 \%$ hingga 10\%. Semakin pesatnya pertumbuhan kedai kopi di Indonesia seiring dengan kreativitas kedai kopi menyajikan kopi kepada konsumen. Channel penjualan kedai kopipun kini semakin berkembang. Tidak hanya tersedia di kedai kopi konvensional pinggir jalan, kini kedai kopi juga bisa dijumpai di berbagai pusat perbelanjaan dan mal-mal besar. Bahkan beberapa minimarket saat ini juga mulai menjual produk minuman kopi dengan brand mereka sendiri. Selain itu, berkembangnya tekhnologi juga membuat kedai kopi kini bisa dipesan melalui aplikasi seluler. Pertumbuhan bisnis ini didukung juga dengan berbagai penawaran kedai kopi yang semakin beragam (Pradika, 2019). Saat ini strategi pemilik kedai kopi sudah menggunakan omnichannel yakni menggabungkan ofline dan online. 


\section{Stevani Korentia Sebayang, Syafrizal Helmi Situmorang}

Dengan banyaknya saluran penawaran kedai kopi secara online maka para penikmat kopi dapat menikmati kopi tanpa harus berkunjung pada kedai kopi tersebut. Pandemi Covid-19 telah menyebabkan orang-orang tidak dapat keluar untuk meminum kopi dari kedai kopi yang mereka inginkan. Banyaknya kedai kopi yang bekerja sama dengan aplikasi online seperti GrabFood dan gofood telah memudahkan para penikmat kopi, disisi lain kedai kopi tersebut dapat mempertahankan penjualan dan pelanggannya tidak beralih ke kedai kopi pesaing. Strategi penjualan kopi secara online juga harus memperhatikan layanan yang baik dan tanggap atas setiap permintaan, keluhan ataupun saran pelanggan agar tetap mempertahankan eksistensi kedai kopi online tersebut agar pelanggan tetap puas dan percaya terhadap pelayanan yang diberikan Kedai kopi online dan menciptakan loyalitas pelanggan dengan mengetahui nilai pelanggan yang diperlukan (Laucereno, 2020). Membangun kepercayaan konsumen harus dibuktikan dengan kreativitas dan inovasi agar pelanggan tidak beralih ke pesaing. Inovasi dapat dilakukan dengan variasi produk, variasi rasa dan didukung dengan promosi. Saat ini persaingan kedai kopi secara online semakin ketat akibat adanya wabah covid-19, oleh karena itu para pengusaha di bidang kedai kopi harus melakukan berbagai inovasi pada bisnisnya agar dapat bertahan dan memenangkan persaingan. Sebelum pandemi, kedai kopi merupakan salah satu bisnis yang cemerlang. Kedai kopi tidak hanya memanfaatkan kopi sebagai daya tarik, tetapi juga atmosfer (servicescape) sebagai tempat berkumpul. Tetapi saat pandemi Covid-19 melanda, hampir semua kedai kopi mengalami penurunan hingga tutup dan sebagian kedai kopi tetap buka dengan melakukan beberapa perubahan, inovasi serta ide-ide kreatif yang diharapkan dapat memenuhi kebutuhan dan keinginan konsumen, sehingga konsumen dapat puas, apabila konsumen puas maka diharapkan konsumen menjadi loyal dan dapat menceritakan hal-hal positif kepada orang lain (Ammurabi, 2020). Jika konsumen telah mempercayai kedai kopi yang disediakan oleh pebisnis kedai kopi tersebut, maka hal itu bisa memungkinkan mereka meningkatkan keinginannya untuk melakukan pembelian secara terus menerus sedangkan seorang pelanggan yang puas adalah pelanggan yang merasa mendapatkan value dari produsen. Value ini bisa berasal dari produk, pelayanan, sistem atau sesuatu yang bersifat emosional. Value bagi pelanggan ini dapat diciptakan melalui atribut-atribut yang dapat menjadi patokan bagi perusahaan untuk mempengaruhi konsumen dalam pembelian (Pine \& Gilmore, 2011).

Nilai pelanggan merupakan salah satu hal penting dalam proses pemasaran. Memahami kebutuhan dan keinginan konsumen menjadikan nilai pelanggan sebagai salah satu hal yang diperhatikan. Dengan memperhatikan nilai pelanggan diharapkan akan terjadinya permintaan atas produk atau jasa yang ditawarkan dan mampu memberikan kepuasan akan tujuan konsumen. Banyak perusahaan yang berlomba-lomba untuk memberikan nilai tambah dalam produk atau jasa, hal ini dianggap penting sehingga menjadi perhatian khusus dalam pembuatan atau produksi suatu produk, dimana konsumen akan membeli produk yang memberikan nilai yang lebih (Saputra, 2012). Berdasarkan uraian latar belakang diatas, maka dirumuskan masalah sebagai berikut: (1) Apakah Nilai Pelanggan berpengaruh positif dan signifikan terhadap loyalitas konsumen pada kedai kopi secara online? (2) Apakah kepuasan pelanggan berpengaruh positif dan signifikan terhadap Loyalitas Konsumen pada kedai kopi secara online? (3) Apakah Kepercayaan berpengaruh positif dan signifikan terhadap Loyalitas Konsumen pada kedai kopi secara online? (4) Apakah Nilai Pelanggan, Kepuasan Pelanggan dan Kepercayaan berpengaruh terhadap Loyalitas Konsumen pada Kedai Kopi Online?

Dengan berkembangnya produk kopi online di Kota Medan dan menimbang bahwa produk minuman kopi adalah hal yang cukup disenangi kaula muda. Maka perlu bagi pihak kedai kopi online di Kota Medan agar terus melakukan inovasi terhadap produknya agar dapat terus bersaing dengan kompetitornya. Pihak kedai kopi online harus menanamkan nilai pelanggan pada produknya sehingga kepuasan pelanggan meningkat. Peningkatan kepuasan 


\section{Stevani Korentia Sebayang, Syafrizal Helmi Situmorang}

pelanggan kedai kopi online di Kota Medan diharapkan akan turut meningkatkan kepercayaan pelanggan terhadap produk kopi online sehingga tercipta pelanggan yang loyal. Peneliti ingin melihat ada atau tidaknya pengaruh Nilai pelanggan. Kepuasan pelanggan dan Kepercayaan terhadap Loyalitas pelanggan pada kedai kopi online di kota Medan. Nilai pelanggan, kepuasan pelanggan, dan kepercayaan mungkin berpengaruh terhadap loyalitas pelanggan namun hal itu bergantung pada bagimana penerapan faktor-faktor tersebut yang diberikan oleh pihak kedai kopi online di kota Medan terhadap pelanggannya.

\section{Landasan Teori \\ Nilai Pelanggan}

Menurut Kotler dan Keller (2016), nilai yang dipersepsikan pelanggan adalah selisih antara penilaian pelanggan yang prospektif atas semua manfaat dan biaya dari suatu penawaran terhadap alternatifnya. Total manfaat pelanggan (total customer value) adalah nilai moneter kumpulan manfaat ekonomi, fungsional dan psikologis yang diharapkan pelanggan dari suatu penawaran pasar yang disebabkan oleh produk, jasa, personel dan citra yang terlibat.. Secara umum, nilai dapat didefinisikan sebagai keyakinan tentang beberapa kondisi akhir yang diinginkan yang melampaui situasi tertentu dan memandu pemilihan perilaku. Perusahaan perlu meningkatkan value yang didapatkan pelanggan demi memuaskan pelanggan dan meningkatkan daya saing perusahaan, nilai yang difokuskan kepada pelanggan pada kualitas tertinggi dengan menjadi lebih baik (Pine \& Gilmore, 2011).

Sementara itu Robinette \& Brand (2010) menyatakan bahwa nilai pelanggan terdiri dari dua jenis yaitu, Rational Value dan Emotional Value, kedua bentuk tersebut dikenal dengan bintang nilai (value Star). Masing-masing nilai terdiri dari:

\section{Rational Value: Product dan Price}

Rational Value di identifikasi pelanggan bahwa nilai adalah harga rendah. Hal ini diterjemahkan perusahaan dengan melakukan berbagai potongan harga pada setiap penawaran. Rational value dapat dilihat melalui elemen-elemen berikut ini:

a. Product/Quality, Merupakan persepsi dari manfaat yang dirasakan pelanggan terhadap kualitas produk atau jasa, apakah sesuai dengan harapan pelanggan. Di sini diperlukan kejelian dan intelejen manajemen untuk mencari dan menangkap kebutuhan dan keinginan yang tersembunyi di hati pelanggan.

b. Money/Price, Product dan price bukan hanya merupakan syarat untuk memasuki pasar namun juga agar produk tersebut tetap bertahan di pasar. Sayangnya, apabila konsumen hanya membeli berdasarkan harga, maka ia hanya loyal terhadap harga, oleh karena itu diperlukan perusahaan perlu menumbuhkan ikatan emosional dengan pelanggan melalui emotional value.

\section{Emotional Value: Equality Value, Experience Value dan Energy Value.}

Emotional Value adalah dengan memahami pelanggan berarti memahami perasaan dan emosi mereka dan akhirnya perusahaan dapat memberikan nilai yang sifatnya emosional dibandingkan rational Value. Nilai emosional menjadi ciri khas bagi suatu perusahaan yang sulit ditiru oleh perusahaan lain. Nilai emosional ini dapat dijelaskan melalui elemen-elemen berikut:

a. Equity/Trust, Equity adalah segala sesuatu yang diterima oleh pelanggan atas dasar 


\section{Stevani Korentia Sebayang, Syafrizal Helmi Situmorang}

kepercayaan dari perusahaan, di mana perusahaan dapat memenuhi janji-janjinya atas brand promises yang dibuatnya, sehingga konsumen merasa memperoleh keberuntungan dan keadilan dari perusahaan.

b. Experience/Relationship, Experience yaitu sekumpulan hasil interaksi antara lembaga dan konsumen pada saat sebelum, sedang, maupun setelah transaksi yang dapat memberikan pengalaman bagi konsumen atas dasar kegiatan-kegiatan servis yang dilakukan oleh perusahaan. Perusahaan dapat menciptakan pengalaman pelanggan dengan menambahkan hiburan pada penawaran pelayanan atau perusahaan dapat melakukannya dengan mengubah pengalaman pelayanan menjadi pengalaman tak terlupakan dengan menciptakan pengalaman pelayanan yang menyenangkan dan memberikan pelayanan istimewa yang tidak dilupakan pelanggan.

c. Energy (Convenience), Energy berhubungan dengan pengorbanan konsumen sehubungan dengan daya dan tenaga yang dihabiskan dalam ukuran waktu, untuk memperoleh jasa. Ukuran waktu ini dapat menyangkut waktu dalam perjalanan, waktu tunggu, dan waktu menikmati servis. Perusahaan provider harus mempertimbangkan segi energi dan waktu ini dalam pelayanan servisnya agar dapat memberikan kenyamanan bagi pelanggan dalam menggunakan produk dan jasa dari perusahaan.

\section{Kepuasan Pelanggan}

Kepuasan pelanggan adalah situasi kognitif pembeli berkenan dengan kesepadanan atau ketidaksepadanan antara hasil yang didapatkan dibandingkan dengan pengorbanan yang dilakukan (Tjiptono, 2018). Menurut Kotler \& Keller (2016), kepuasan konsumen adalah tingkat perasaan seseorang setelah membandingkan (kinerja atau hasil) yang dirasakan dibandingkan dengan harapannya. Konsumen dapat mengalami salah satu dari tiga tingkat kepuasan umum yaitu kalau kinerja di bawah harapan, konsumen akan merasa kecewa tetapi jika kinerja sesuai dengan harapan pelanggan akan merasa puas dan apa bila kinerja bisa melebihi harapan maka pelanggan akan merasakan sangat puas senang atau gembira.

Definisi kepuasan pelanggan menurut Kotler dan Amstrong (2015) ialah Perasaan senang atau kecewa yang muncul setelah membandingkan kinerja (hasil) produk yang dipikirkan terhadap kinerja (atau hasil) yang diharapkan. Pelanggan yang sangat tidak puas dapat berubah menjadi "teroris"bagi penyedia layanan dengan menyebarkan kata-kata negative dari mulut ke mulut dalam kelimpahan (Lovelock \& Wirtz, 2018).

Menurut Gunawan, Sebastian, \& Harianto (2019), kepuasan konsumen memiliki alat ukur atau indikator sebagai berikut:

\section{Fulfillment}

Kata fulfillment menurut kamus Oxford bisa diartikan sebagai pencapaian sesuatu yang diinginkan atau memenuhi persyaratan, kondisi atau kebutuhan. Fulfillment juga bisa diartikan sebagai perasaan puas atas kebutuhan yang terpenuhi sesuai dengan ekspektasi konsumen.

2. Pleasure

Pleasure dalam kamus Oxford diartikan sebagai perasaan kepuasan yang menyenangkan dan kenikmatan atau sesuatu yang membuat orang puas. Pleasure bertumpu reaksi seseorang terhadap "lingkungan" dimana barang atau jasa itu diterima.

\section{Ambivalence}

Ambivalence seperti pengertian di kamus Oxford yaitu keadaan suatu perasaan campur aduk dan saling bertentangan tentang sesuatu atau seseorang. Ambivalence mengacu 
pada perasaan seseorang dimana ada ketakutan dalam diri seseorang tetapi disisi lain ada harapan.

\section{Kepercayaan}

Kepercayaan merek merupakan sebuah perilaku kerelaan konsumen pada umumnya untuk bergantung pada kemampuan merek tersebut menggambarkan fungsi produknya, mendefinisikan kepercayaan terhadap merek (brand trust) sebagai kemauan dari rata-rata konsumen untuk bergantung kepada kemampuan dari sebuah merek dalam melaksanakan segala kegunaan atau fungsinya. Secara spesifik, kepercayaan dapat mengurangi ketidakpastian dalam sebuah lingkungan di mana konsumen merasa tidak aman di dalamnya, karena mereka mengetahui bahwa mereka dapat mengandalkan merek yan $\mathrm{g}$ sudah dipercaya tersebut (Chaudhuri \& Holbrook 2001).

Kepercayaan kepada merek biasa disebut Brand Trust. Brand Trust didefinisikan sebagai keinginan pelanggan untuk bersandar pada sebuah merek dengan resiko-resiko yang dihadapi karena ekspektasi terhadap merek itu akan menyebabkan hasil yang positif, terdapat tiga faktor yang mempengaruhi kepercayaan terhadap merek. Ketiga faktor ini berhubungan tiga entitas yang tercakup dalam hubungan antara merek dan konsumen. Adapun ketiga faktor tersebut adalah merek itu sendiri, perusahaan, pembuat merek, dan konsumen Menurut Ling et al (2010) dimensi kepercayaan meliputi keamanan, privasi dan keandalan. Ketiga faktor tersebut dapat dijelaskan sebagai berikut:

\section{Keamanan}

Didefinisikan sebagai sejauh mana pelanggan percaya bahwa jual beli online aman bagi mereka untuk mengirimkan informasi sensitif terhadap transaksi bisnis. Keamanan berperan penting dalam mempengaruhi sikap dan minat beli karena dianggap memiliki resiko transmisi informasi seperti nomor kartu kredit dan lain-lain.

2. Privasi

Didefinisikan sebagai menjaga segala perilaku konsumen selama transaksi yang kemudian berkaitan dengan kinerja

3. Keandalan

Perusahaan dapat mempengaruhi kepercayaan konsumen. Dalam lingkungan web-shopping sebagian besar konsumen menganggap bahwa perusahaan besar memiliki kemampuan yang lebih baik untuk meningkatkan kepercayaan online mereka. Hal ini juga mengusulkan bahwa sebuah perusahaan dengan reputasi positif yang meningkatkan kepercayaan konsumen

\section{Loyalitas Pelanggan}

Loyalitas pelanggan memliki peran penting dalam sebuah perusahaan, mempertahankan pelanggan berarti meningkatkan kinerja keuangan dan mempertahankan kelangsungan hidup perusahaan, secara harfiah loyal berarti setia atau loyalitas diartikan sebagai suatu kesetiaan, kesetiaan ini sesuatu yang timbul tanpa adanya paksaan tetapi timbul dari keadaan sendiri. Pelanggan yang loyal merupakan aset bagi perusahaan, hal ini dapat dilihat berdasarkan karateristik yang dimilikinya. Oleh karena itu, loyalitas konsumen merupakan suatu yang bisa diandalkan untuk memprediksi pertumbuhan dimasa yang akan datang bagi suatu perusahaan (Kotler \& Keller, 2016). Loyalitas pelanggan merupakan perilaku pelanggan dimana pelanggan mengambil keputusan untuk melakukan pembeliaan barang atau jasa secara terus menerus (Pramita, 2015). Loyallitas pelanggan merupakan salah satu faktor yang menjadi kunci dalam kelangsungan hidup bisnis dan pengembangan 
lingkungan hidup yang kompetitif. Loyalitas pelanggan yang sudah ada harus dipertahankan karena biaya untuk mendapatkan pelanggan yang baru hampir lima kali biaya untuk mempertahankan pelanggan lama (Dewi, 2017).

Dalam perusahaan pelanggan yang loyal merupakan aset penting, hal ini dapat dilihat dari karakteristik yang dimilikinya, sebagaimana yang diungkapkan oleh (Lovelock \& Wirtz, 2018) diikuti oleh Griffin, pelanggan yang loyal memiliki karakteristik sebagai berikut:

1. Melakukan pembelian berulang secara teratur.

Komitmen untuk membeli kembali merupakan sikap yang paling penting bagi loyalitas, bahkan lebih penting dari kepuasan. Singkatnya, tanpa pembelian berulang, tidak ada loyalitas. Keputusan membeli kembali seringkali merupakan langkah selanjutnya yang terjadi secara alamiah bila pelanggan telah memiliki ikatan emosional yang kuat dengan produk atau jasa tertentu.

2. Untung dari sensitivitas harga yang lebih rendah yang memungkinkan harga premium.

Pelanggan baru sering mendapat manfaat dari diskon promosi pengantar, sedangkan pelanggan jangka panjang lebih cenderung membayar harga reguler. Ketika mereka sangat puas, mereka cenderung kurang sensitif terhadap harga.

3. Mereferensikan kepada orang lain

Refrensi adalah jalur yang paling kuat bagi bisnis manapun untuk dapat sukses merekrut para pelanggan baru. Refrensi juga sangat efektif karena refrensi itu datang dari pihak kedua yang terpercaya.

\section{Kerangka Konseptual}

Dalam penelitian kuantitaf, kerangka berpikir merupakan model konseptual tentang bagaimana teori berhubungan dengan berbagai faktor yang telah diidentifikasi sebagai masalah yang penting (Sugiyono, 2019).

Kerangka konseptual menggambarkan hubungan dari variabel indpenden yaitu Nilai pelangan $\left(\mathrm{X}_{1}\right)$, Kepuasan Pelanggan $\left(\mathrm{X}_{2}\right)$, Kepercayaan $\left(\mathrm{X}_{3}\right)$ dengan variabel dependen yaitu Loyalitas Konsumen (Y).

1. Hubungan Nilai Pelanggan terhadap Loyalitas Konsumen

Harapan pelanggan merupakan standar atau referensi pelanggan dengan pelanggan yang diterimanya, ekspetasi pelanggan terdiri dai apa yang diyakini oleh pelanggan.

2. Hubungan Kepuasan Pelanggan terhadap Loyalitas Konsumen

Kepuasan konsumen adalah tingkat perasaan seseorang setelah membandingkan (kinerja atau hasil) yang dirasakan dibandingkan dengan harapannya ( Kotler \& Keller, 2016)

3. Hubungan Kepercayaan terhadap Loyalitas Konsumen

Bagi konsumen, untuk membuka hubungan dengan suatu merek, makan konsumen harus menyukai dahulu merek tersebut. Kepercayaan sangat tergantung dengan pengalaman konsumen akan suatu merek, kepuasan tersebut akan menentukan besarnya kepercayaan merek yang pada akhirnya akan mempengaruhi brand loyalty konsumen pada merek tersebut.

Nilai Pelanggan

$\left(\mathbf{X}_{1}\right)$ 

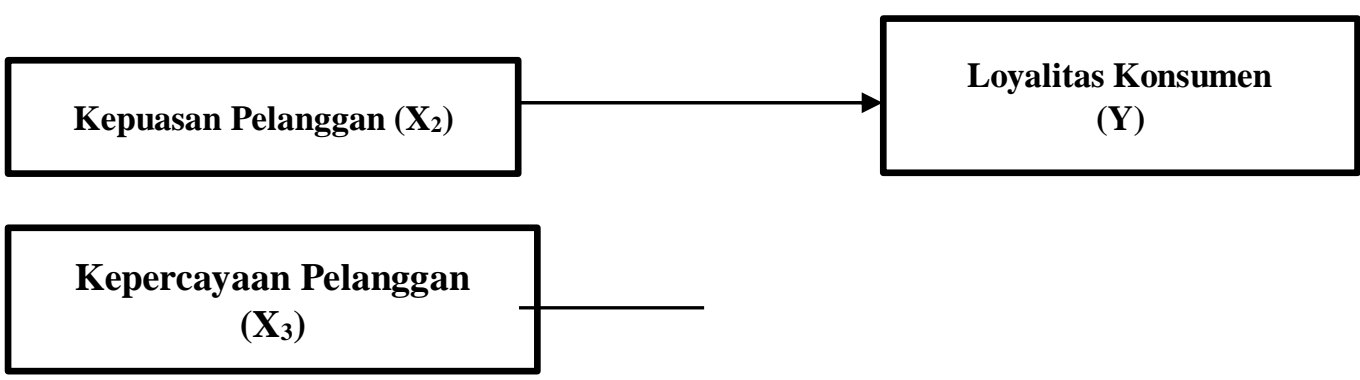

\section{Gambar 1. Kerangka Konseptual}

Berdasarkan teori yang telah dipaparkan, maka rumusan masalah dalam penilitian ini, yaitu:

1. Nilai Pelanggan berpengaruh positif dan signifikan terhadap Loyalitas Konsumen pada Kedai Kopi Online Medan

2. Kepuasan Pelanggan berpengaruh positif dan signifikan terhadap Loyalitas Konsumen pada Kedai Kopi Online Medan

3. Kepercayaan Pelanggan berpengaruh positif dan signifikan terhadap Loyalitas Konsumen pada Kedai Kopi Online Medan.

4. Nilai Pelanggan, Kepuasan Konsumen, dan Kepercayaan berpengaruh positif dan signifikan terhadap Loyalitas Konsumen pada Kedai Kopi Online Medan.

\section{Metode Penelitian}

Penelitian ini dilakukan dengan mengamati tiga kedai kopi secara online yang ada di kota medan dengan sampel 150 pelanggan kedai kopi di kota Medan . Penelitian ini dilakukan sejak juni 2020 sampai juli 2020. Dalam penelitian ini variabel dibagi menjadi dua kelompok, yaitu variabel bebas (independent variable), dan variabel terikat (dependent variable). Defenisi masing-masing variabel adalah sebagai berikut:

1. Variabel Bebas (independent variable) yaitu variabel yang mempengaruhi atau yang menjadi sebab perubahan atau timbulnya variabel dependen (Sugiyono, 2017). Dalam penelitian ini, yang menjadi variabel bebas adalah Nilai Pelanggan $\left(\mathrm{X}_{1}\right)$, Kepuasan Pelanggan $\left(\mathrm{X}_{2}\right)$, dan Kepercayaan $\left(\mathrm{X}_{3}\right)$.

a. Nilai Pelanggan $\left(\mathrm{X}_{1}\right)$, Perusahaan perlu meningkatkan value yang didapatkan pelanggan demi memuaskan pelanggan dan meningkatkan daya saing perusahaan, nilai yang difokuskan kepada pelanggan padakualitas tertinggi dengan menjadi lebih baik (Pine \& Gilmore, 2011). Robinette \& Brand (2010) menyatakan bahwa nilai pelanggan terdiri dari dua jenis yaitu, Rational Value: (Product dan Price) dan Emotional Value: (Equality value, Experience Value dan Energy Value).

b. Kepuasan Pelanggan $\left(\mathrm{X}_{2}\right)$, Menurut Kotler \& Keller (2016), kepuasan konsumen adalah tingkat perasaan seseorang setelah membandingkan (kinerja atau hasil) yang dirasakan dibandingkan dengan harapannya.

c. Kepercayaan $\left(\mathrm{X}_{3}\right)$, Secara spesifik, kepercayaan dapat mengurangi ketidakpastian dalam sebuah lingkungan di mana konsumen merasa tidak aman di dalamnya, karena mereka mengetahui bahwa mereka dapat mengandalkan merek yang sudah dipercaya tersebut (Chaudhuri \& Holbrook 2001).

2. Variabel Terikat (dependent variable) yaitu variabel yang dipengaruhi atau yang menjadi akibat karena adanya variabel bebas (Sugiyono, 2017). Dalam penelitian ini, yang 
menjadi variabel terikat adalah Loyalitas Konsumen (Y).

a. Loyalitas Konsumen (Y), Loyalitas pelanggan memliki peran penting dalam sebuah perusahaan, mempertahankan pelanggan berarti meningkatkan kinerja keuangan dan mempertahankan kelangsungan hidup perusahaan, secara harfiah loyal berarti setia atau loyalitas diartikan sebagai suatu kesetiaan, kesetiaan ini sesuatu yang timbul tanpa adanya paksaan tetapi timbul dari keadaan sendiri.

Hipotesis dalam penelitian ini, yaitu :

1. Nilai Pelanggan berpengaruh positif dan signifikan terhadap Loyalitas Konsumen pada Kedai Kopi Online Medan

2. Kepuasan Pelanggan berpengaruh positif dan signifikan terhadap Loyalitas Konsumen pada Kedai Kopi Online Medan

3. Kepercayaan Pelanggan berpengaruh positif dan signifikan terhadap Loyalitas Konsumen pada Kedai Kopi Online Medan.

4. Nilai Pelanggan, Kepuasan Konsumen, dan Kepercayaan berpengaruh positif dan signifikan terhadap Loyalitas Konsumen pada Kedai Kopi Online Medan

Metode pengumpulan data dalam penelitian ini yang digunakan adalah data primer dan data sekunder yang diperoleh melalui studi dokumentasi dan daftar pertanyaan yang pengukurannya menggunakan skala interval.

Suatu pernyataan dikatakan valid apabila nilai $r$ hitung $>r$ tabel. Diketahui seluruh nilai $r$ hitung $>r$ tabel (0.361). Sehingga disimpulkan seluruh pernyataan pada variabel nilai pelanggan, kepuasan pelanggan kepercayaan dan loyalitas pelangan telah valid. Validitas menunjukan sejauh mana suatu alat pengukur itu mengukur apa yang ingin diukur (Situmorang, 2017).

Uji reliabilitas dilakukan untuk menunjukkan sejauh mana, metode yang digunakan dalam pengujian reliabilitas ini adalah menggunakan Cronbach Alpha dengan kriteria pengambilan keputusan menurut Hair et al (2013), yaitu jika koefisien Cronbach Alpha> 0.50 maka kuesioner dinyatakan sudah memuaskan (reliable). Diketahui bahwa nilai Cronbach Alpha pada vaiabel nilai pelanggan, kepuasan pelanggan, kepercayaan dan loyalitas pelanggan adalah $0.777,0.671,0.752$, dan 0.753 lebih besar dari 0.50, sehingga kuesioner telah reliable.

Tujuan utama pemberian defenisi operasional adalah suatu defenisi yang diberikan pada suatu variabel dengan cara memberikan arti atau menspesifikasikan kegiatan, ataupun memberikan suatu operasional yang diperlukan untuk mengukur variabel tersebut.

Tabel 1. Operasional Variabel Penelitian

\begin{tabular}{|c|c|c|c|}
\hline Variabel & Defenisi Operasional & Indikator & Skala \\
\hline $\begin{array}{l}\text { Loyalitas } \\
\text { Konsumen }\end{array}$ & $\begin{array}{l}\text { Loyalitas pelanggan merupakan } \\
\text { kecenderungan pelanggan untuk memilih } \\
\text { nilai organisasi yang ditawarkan diatas } \\
\text { alternatif tawaran organisasi pesaing, dengan } \\
\text { loyalitas yang diperkuat dengan komitmen } \\
\text { diantara organisasi/perusahaan dan } \\
\text { pelangganakan lebih meningkatkan hubungan } \\
\text { yang lebih dekat dalam penjaminan } \\
\text { pemenuhan kebutuhan dan keinginan } \\
\text { pelanggan }\end{array}$ & $\begin{array}{ll}\text { 1. } & \text { Pembelian Ulang } \\
\text { 2. } & \text { Sensitifitas Harga } \\
\text { 3. } & \text { Word Of Mouth }\end{array}$ & Interval \\
\hline
\end{tabular}


Stevani Korentia Sebayang, Syafrizal Helmi Situmorang

\begin{tabular}{|c|c|c|c|}
\hline $\begin{array}{l}\text { Nilai } \\
\text { Pelanggan }\end{array}$ & $\begin{array}{l}\text { nilai yang dipersepsikan pelanggan adalah } \\
\text { selisih antara penilaian pelanggan yang } \\
\text { prospektif atas semua manfaat dan biaya dari } \\
\text { suatun penawaran terhadap alternatifnya. }\end{array}$ & $\begin{array}{ll}\text { 1. } & \text { Produk } \\
\text { 2. } & \text { Harga } \\
\text { 3. } & \text { Kepercayaan } \\
\text { 4. } & \text { Experience } \\
\text { 5. } & \text { Energy }\end{array}$ & Interval \\
\hline $\begin{array}{l}\text { Kepuasan } \\
\text { Pelanggan }\end{array}$ & $\begin{array}{l}\text { Kepuasan konsumen adalah tingkat perasaan } \\
\text { seseorang setelah membandingkan (kinerja a } \\
\text { ltau hasil) yang dirasakan dibandingkan dengan } \\
\text { harapannya. Konsumen dapat mengalami salah } \\
\text { satu dari tiga tingkat kepuasan umum yaitu } \\
\text { kalau kinerja di bawah harapan, konsumen akan } \\
\text { merasa kecewa tetapi jika kinerja sesuai dengan } \\
\text { harapan pelanggan akan merasa puas dan apa } \\
\text { bila kinerja bisa melebihi harapan maka } \\
\text { pelanggan akan merasakan sangat puas senang } \\
\text { atau gembira. }\end{array}$ & $\begin{array}{ll}\text { 1. } & \text { Fulfillment } \\
\text { 2. } & \text { Pleasure } \\
\text { 3. } & \text { Ambivalence }\end{array}$ & Interval \\
\hline $\begin{array}{l}\text { Kepercayan } \\
\text { Pelanggan }\end{array}$ & $\begin{array}{l}\text { kepercayaan adalah kesediaan konsumen } \\
\text { untuk mempercayai dengan segala resikonya } \\
\text { karena adanya harapan di benak mereka } \\
\text { bahwa merek tersebut akan memberikan hasil } \\
\text { yang positif kepada konsumen sehingga akan } \\
\text { menimbulkan kesetiaan. }\end{array}$ & $\begin{array}{ll}1 & \text { Keamanan } \\
2 & \text { Privasi } \\
3 & \text { Keandalan }\end{array}$ & Interval \\
\hline
\end{tabular}

Metode analisis yang digunakan dalam penelitian ini adalah metode analisis deskriptif dan analisis regresi linear berganda yang diolah dengan software SPSS for windows.

\section{Hasil Penelitian}

Analisis Deskriptif Responden

Tabel 2. Deskritif Responden

\begin{tabular}{|c|l|r|r|}
\hline $\begin{array}{c}\text { Karateristik Responden } \\
\text { Berdasarkan }\end{array}$ & Frequency & $\begin{array}{c}\text { Valid } \\
\text { Percent }\end{array}$ \\
\hline \multirow{5}{*}{ Jenis Kelamin } & Pria & 74 & 49.3 \\
& Total & 76 & 50.7 \\
\hline \multirow{5}{*}{ Umur } & $<17$ Tahun & 150 & 100.0 \\
\hline & $18-22$ Tahun & 27 & 18.0 \\
& 23-27 Tahun & 43 & 28.7 \\
& 28-32 Tahun & 25 & 28.0 \\
& $33-37$ Tahun & 8 & 16.7 \\
& 38-42 Tahun & 2 & 5.3 \\
& $>42$ Tahun & 3 & 1.3 \\
& & & 2.0 \\
& Total & 150 & 100.0 \\
\hline Pekerjaan & Pelajar/Mahasiswa & 58 & 38.7 \\
& Wirausaha & 26 & 17.3 \\
& Pegawa & 42 & 28.0 \\
& Negeri/Swasta & 24 & 16.0 \\
\hline
\end{tabular}


INOBIS: Jurnal Inovasi Bisnis dan Manajemen Indonesia

Volume 02, Nomor 02, Bulan Maret 2019

Stevani Korentia Sebayang, Syafrizal Helmi Situmorang

\begin{tabular}{|c|c|c|c|}
\hline & $\begin{array}{l}\text { Tidak Bekerja } \\
\text { Total }\end{array}$ & 150 & 100.0 \\
\hline \multirow{5}{*}{ Alasan Pembeliaan } & Murah & 61 & 40.7 \\
\hline & Praktis & 47 & 31.3 \\
\hline & Reputasi Baik & 26 & 17.3 \\
\hline & Eksistensi & 16 & 10.7 \\
\hline & Total & 150 & 100.0 \\
\hline \multirow{5}{*}{ Berapa Kali Pembelian } & $1-2$ kali & 20 & 13.3 \\
\hline & 3-4 kali & 74 & 49.3 \\
\hline & 5-6 kali & 37 & 24.7 \\
\hline & $>6$ kali & 19 & 12.7 \\
\hline & Total & 150 & 100.0 \\
\hline \multirow{4}{*}{$\begin{array}{c}\text { Pemebelian Dalam Satu } \\
\text { Minggu }\end{array}$} & $1-2$ kali & 120 & 80.0 \\
\hline & 3-4 kali & 23 & 15.3 \\
\hline & 5-6 kali & 7 & 4.7 \\
\hline & Total & 150 & 100.0 \\
\hline \multirow{5}{*}{$\begin{array}{l}\text { Terakhir Kali } \\
\text { Pembelian }\end{array}$} & 1 minggu yang lalu & 38 & 25.3 \\
\hline & 2 minggu yang lalu & 60 & 40.0 \\
\hline & 3 minggu yang lalu & 28 & 18.7 \\
\hline & 4 minggu yang lalu & 21 & 16.0 \\
\hline & Total & 150 & 100.0 \\
\hline
\end{tabular}

Berdasarkan Tabel 2 dapat diketahui bahwa total responden penelitian yang berjumlah 150 orang dengan jenis kelamin pria sebanyak 74 orang $(49,3 \%)$ dan wanita sebanyak 76 orang $(50,7 \%)$. Dari tabel diatas dapat disimpulkan bahwa pelanggan yang membeli produk kopi online di Kota Medan lebih banyak yang berumur 22-27 Tahun atau dapat dikatakan kaum milenial dengan kategori pekerjaan mayoritas adalah pelajar/mahasiswa sebanyak $58(38,7 \%)$ responden, pelanggan lebih banyak membeli produk kopi online di Kota Medan dengan alasan murah dan sudah perrnah membeli 3-4 kali dengan frekuensi pembelian mayoritas 1-2 kali perminggu dan dapat dilihat pada tabel 2 pelanggan kedai kopi online, paling banyak terakhir kali membeli pada waktu 2 minggu yang lalu. 
INOBIS: Jurnal Inovasi Bisnis dan Manajemen Indonesia

Volume 02, Nomor 02, Bulan Maret 2019

Stevani Korentia Sebayang, Syafrizal Helmi Situmorang

\section{Analisis Deskriptif Variabel}

Tabel 3. Deskriptif Variabel

\begin{tabular}{|c|c|c|}
\hline \multirow{6}{*}{ Nilai Pelanggan } & Item & Rata-Rata \\
\hline & $\begin{array}{l}\text { Sesuai dengan } \\
\text { keinginan }\end{array}$ & 3.11 \\
\hline & $\begin{array}{l}\text { Harga sesuai } \\
\text { dengan manfaat }\end{array}$ & 3.17 \\
\hline & $\begin{array}{l}\text { Dapat memberikan } \\
\text { produk yang sesuai }\end{array}$ & 3.19 \\
\hline & $\begin{array}{l}\text { Pengalaman yang } \\
\text { menyenangkan }\end{array}$ & 3.11 \\
\hline & $\begin{array}{l}\text { Manfaat sesuai } \\
\text { dengan energy yang } \\
\text { dikeluarkan }\end{array}$ & 3.14 \\
\hline \multirow{4}{*}{$\begin{array}{l}\text { Kepuasan } \\
\text { Pelanggan }\end{array}$} & Item & Rata-rata \\
\hline & $\begin{array}{l}\text { Harga sesuai dengan } \\
\text { kualitas }\end{array}$ & 3.15 \\
\hline & Merasa senang & 3.17 \\
\hline & $\begin{array}{l}\text { Tetap memiliki } \\
\text { harapan/ekspetasi } \\
\text { walau ada keraguan } \\
\end{array}$ & 3.05 \\
\hline \multirow{4}{*}{ Kepercayaan } & Item & Rata-rata \\
\hline & $\begin{array}{l}\text { Merasa aman ketika } \\
\text { mengkonsumsi }\end{array}$ & 3.09 \\
\hline & $\begin{array}{l}\text { Tidak merugikan } \\
\text { ketika membeli }\end{array}$ & 3.17 \\
\hline & $\begin{array}{l}\text { Memiliki reputasi } \\
\text { yang baik }\end{array}$ & 3.17 \\
\hline \multirow{4}{*}{ Loyalitas pelanggan } & Item & Rata-rata \\
\hline & $\begin{array}{l}\text { Melakukan pembelian } \\
\text { ulang }\end{array}$ & 3.13 \\
\hline & $\begin{array}{l}\text { Tidak beralih } \\
\text { walaupun harga naik }\end{array}$ & 3.15 \\
\hline & $\begin{array}{l}\text { Merekomendasikan } \\
\text { produk }\end{array}$ & 3.23 \\
\hline
\end{tabular}

Dapat dilihat dari tabel 3, kedai kopi online memberikan produk yang sesuai pada nilai pelanggan memiliki rata-rata yang paling tinggi, karna berdasarkan penelitian citra positif akan memberikan tanggung jawab pihak kedai kopi online dalam memberikan produk sesuai dengan yang dijanjikan kepada konsumen, seperti bahan kopi yang berkualitas baik. Dari hasil penelitian, pelanggan dapat merasa senang ketika mengkonsumsi produk kopi online memiliki rata rata paling besar, dapat di lihat dari tabel 3 pada variabel kepuasan konsumen. Karena pihak kedai kopi online memberikan produk dengan bahan berkualitas tinggi serta racikan kopi yang berasal dari perpaduan biji-bijian kopi dari berbagai daerah dan 
berbagai variasi menu yang tersedia. Pada variabel kepercayaan, terdapat perrnyataan pelanggan meras aman ketika mengkonsumsi produk kopi online dengan rata-rata paling kecil yaitu 3,09\%. Berdasarkan penelitian sebagian pelanggan kedai kopi online yang masih meragukan produk ketika sampai pada pelanggan, seperti packaging yang kurang rapi sehingga mengakibatkan produk kopi tidak sesuai dengan yang diinginkan. Sedangkan dari hasil penelitian pada variabel loyalitas pelanggan yang ada pada tabel 3 menyatakan pelanggan merekomendasikan produk kopi online kepada orang lain, yang memililiki ratarata paling besar dikarenakan pihak kedai kopi mampu memenuhi keinginan pelanggan seperti rasa yang nikmat, harga yang sesuai dengan kualitas produk dan packaging yang rapi ketika sampai pada pelanggan sehingga ingin orang lain ikut untuk menikmati hal yang sama.

\section{Uji Hipotesis}

\section{Koefisien Determinasi $\left(\mathbf{R}^{2}\right)$}

Tabel 4. Koefisien Determinasi $\left(\mathrm{R}^{2}\right)$

Model Summary ${ }^{b}$

\begin{tabular}{l|l|l|l|l|}
\hline Model & $R$ & R Square & $\begin{array}{l}\text { Adjusted R } \\
\text { Square }\end{array}$ & $\begin{array}{l}\text { Std. Error of the } \\
\text { Estimate }\end{array}$ \\
\hline & \multicolumn{1}{|c|}{$687^{\mathrm{a}}$} & .472 & .462 & 2.16376 \\
\hline
\end{tabular}
a. Predictors: (Constant), Kepercayaan (X3), Kepuasan Pelanggan (X2),
Nilai Pelanggan (X1)
b. Dependent Variable: Loyalitas Pelanggan (Y)
Sumber: Hasil Pengolahan SPSS, 2020 (data diolah)

Berdasarkan Tabel 4, diketahui nilai Adjusted $R$ Square adalah 0,462. Nilai tersebut dapat diartikan variabel nilai pelanggan, kepuasan pelanggan dan kepercayaan mampu mempengaruhi loyalitas pelanggan sebesar 46,2\%, sisanya sebesar 53,8\% dijelaskan oleh variabel atau faktor lainnya.

\section{Uji Signifikan Simultan (Uji-F)}

Tabel 5. Uji Signifikan Simultan (Uji-F)

\begin{tabular}{|l|r|r|r|r|l|}
\hline Model & Sum of Squares & df & Mean Square & F & Sig. \\
\hline Regression & 611.940 & 3 & 203.980 & 43.568 & \\
Residual & 683.554 & 146 & 4.682 & \\
Total & 1295.493 & 149 & & \\
a. Predictors: (Constant), Kepercayaan (X3), Kepuasan Pelanggan (X2), Nilai Pelanggan (X1) \\
b. Dependent Variable: Loyalitas Pelanggan (Y) \\
Sumber: Hasil Pengolahan SPSS, 2020 (data diolah) \\
\hline
\end{tabular}

Berdasarkan Tabel 5, diketahui nilai $\mathrm{F}$ hitung 43,568 dan nilai Sig. adalah 0,000. Maka nilai $\mathrm{F}$ tabel dengan df1 $=3$, df $2=146$ dan tingkat signifikansi 5\% atau 0,05 adalah 2,666. Diketahui nilai F hitung 43,568 > F tabel 2,666 dan nilai Sig adalah 0,000 < 0,05, maka nilai pelanggan, kepuasan pelanggan dan kepercayaan pelanggan secara bersama-sama atau serempak berpengaruh signifikan terhadap loyalitas pelanggan. 


\section{Uji Signifikan Parsial (Uji-T)}

Tabel 6. Uji Signifikansi Parsial (Uji-t)

\begin{tabular}{|c|c|c|c|c|c|c|c|}
\hline \multirow[b]{2}{*}{ Model } & \multicolumn{2}{|c|}{$\begin{array}{l}\text { Unstandardized } \\
\text { Coefficients }\end{array}$} & $\begin{array}{l}\text { Standardized } \\
\text { Coefficients }\end{array}$ & & \multirow[b]{2}{*}{ Sig. } & \multicolumn{2}{|c|}{$\begin{array}{l}\text { Collinearity } \\
\text { Statistics }\end{array}$} \\
\hline & B & Std. Error & $\mathrm{ta}^{\mathrm{Be}}$ & & & Tolerance & VIF \\
\hline (Constant) & 1.340 & .743 & & 1.804 & .073 & & \\
\hline Nilai Pelanggan (X1) & .184 & .060 & .26 & 3.056 & .003 & .499 & 2.004 \\
\hline Kepuasan Pelanggan (X2) & .276 & .085 & .26 & 3.231 & .002 & .560 & 1.787 \\
\hline Kepercayaan (X3) & .286 & .074 & $\begin{array}{r}.29 \\
2\end{array}$ & 3.860 & .000 & .632 & 1.583 \\
\hline
\end{tabular}

a. Dependent Variable: Loyalitas Pelanggan (Y)

Sumber: Hasil Pengolahan SPSS, 2020 (data diolah)

Berdasarkan hasil uji t pada Tabel 6 diperoleh hasil:

1. Variabel Nilai Pelanggan (X1)

Diketahui nilai koefisien dari nilai pelanggan adalah 0,184 , yakni bernilai positif. Hal ini berarti nilai pelanggan berpengaruh positif terhadap loyalitas pelanggan. Diketahui nilai statistik t (thitung) adalah $|3,056|>$ ttabel $|1,97|$ dengan Sig dari variabel nilai pelanggan adalah $0,003<0,05$, maka nilai pelanggan berpengaruh signifikan terhadap loyalitas pelanggan.

2. Variabel Kepuasan Pelanggan (X2)

Diketahui nilai koefisien dari kepuasan pelanggan adalah 0,276, yakni bernilai positif. Hal ini berarti kepuasan pelanggan berpengaruh positif terhadap loyalitas pelanggan. Diketahui nilai statistik $t$ (thitung) adalah $|3,231|>$ ttabel $|1,97|$ dengan Sig dari variabel iklan adalah $0,002<0,05$, maka kepuasan pelanggan berpengaruh signifikan terhadap loyalitas pelanggan.

3. Variabel Kepercayaan (X3)

Diketahui nilai koefisien dari kepercayaan adalah 0,286, yakni bernilai positif. Hal ini berarti kepercayaan berpengaruh positif terhadap loyalitas pelanggan. Diketahui nilai statistik t (thitung) adalah $|3,860|>$ ttabel $|1,97|$ dengan Sig dari variabel kepercayaan adalah $0,000<0,05$, maka nilai pelanggan berpengaruh signifikan terhadap loyalitas pelanggan.

\section{Pembahasan}

1. Hasil uji-t (parsial) dalam penelitian ini menunjukkan bahwa nilai pelanggan berpengaruh signifikan terhadap loyalitas pelanggan. Hal ini dibuktikan dengan melihat tabel uji statistik t. Pada tabel tersebut diperoleh nilai signifikansi sebesar 0,003 yang mana lebih kecil dari 0,05 . Kemudian diketahui nilai statistik t (thitung) adalah $|3,056|>\mathrm{t}$ tabel $|1,97|$ yang menunjukkan bahwa variabel nilai pelanggan berpengaruh signifikan terhadap loyalitas pelanggan.

Transaksi akan terjadi bila harga yang yang ditetapkan pada produk disepakati penjual maupun pembeli, dengan adanya perhatian dari pihak kedai kopi online dengan memberikan promo kepada konsumen dapat meningkatkan nilai- nilai yang memberikan kesan baik. Apabila pelanggan memperoleh persepsi nilai yang lebih tinggi dari apa yang diharapkan, maka akan menimbulkan kepuasan pelanggan yang 
kemudian akan mendorong kesetiaan pelanggan makin tinggi.

2. Hasil uji-t (parsial) dalam penelitian ini menunjukkan bahwa kepuasan pelanggan berpengaruh signifikan terhadap loyalitas pelanggan. Hal ini dibuktikan dengan melihat tabel uji statistik t. Pada tabel tersebut diperoleh nilai signifikansi sebesar 0,002 yang mana lebih kecil dari 0,05 . Kemudian diketahui nilai statistik $t$ (thitung) adalah $|3,231|>\mathrm{t}$ tabel $|1,97|$ yang menunjukkan bahwa variabel kepuasan pelanggan berpengaruh signifikan terhadap loyalitas pelanggan.

Konsumen yang merasakan kepuasan di hatinya memiliki pengalaman berbeda menyebabkan keinginan untuk mengunjungi kembali serta menceritakannya kepada lingkungan pribadinya masing-masing. Loyalitas tidak tercipta jika tanpa kepuasan, sehingga semakin tinggi kepuasan maka pelanggan akan semakin loyal.

3. Hasil uji-t (parsial) dalam penelitian ini menunjukkan bahwa kepercayaan berpengaruh signifikan terhadap loyalitas pelanggan. Hal ini dibuktikan dengan melihat tabel uji statistik t. Pada tabel tersebut diperoleh nilai signifikansi sebesar 0,000 yang mana lebih kecil dari 0,05. Kemudian diketahui nilai statistik t (thitung) adalah $|3,860|>\mathrm{t}$ tabel |1,97| yang menunjukkan bahwa variabel kepercayaan berpengaruh signifikan terhadap loyalitas pelanggan.

Hal ini menunjukkan upaya yang ada dalam membangun kepercayaan konsumen melalui pemenuhan kebutuhan atau keinginan konsumen akan produk kedai kopi online. Sebelum suatu produk dibeli oleh konsumen, produsen dan perusahaan harus dapat memperoleh kepercayaan pelanggan terhadap produk yang ditawarkan, untuk menarik perhatian dan minat pelanggan kepada pelanggan, serta kepercayaan pelanggan terhadap produk yang dijual

Tujuan utama dari penelitian ini adalah untuk mengetahui pengaruh nilai pelanggan terhadap loyalitas pada kedai kopi online di kota Medan, pengaruh kepuasan pelanggan terhadap loyalitas pelanggan pada kedai kopi online di kota Medan dan pengaruh kepercayaan terhadap loyalitas pelanggan pada kedai kopi online di kota Medan. Hasil penelitian ini sejalan dengan penelitian sebelumnya menunjukkan hasil bahwa nilai pelanggan berpengaruh positif dan signifikan terhadap loyalitas pelanggan, pelanggan yang menghargai value yang telah diterimanya akan menjadi loyal, dimana pelanggan tersebut akan merekomendasikan pada orang lain jika mereka menerima value yang tinggi (Nawarini, 2019). Penelitian lainnya juga menunjukkan hasil yang sama bahwa terdapat pengaruh yang positif dan signifikan dari customer satisfaction terhadap customer loyalty, pengaruh pelanggan tersebut akan loyal atau tidak didasari oleh banyaknya pertumbuhan sejenis, sehingga perusahaan harus dapat memperhatikan kenyamanan dan kecepatan dalam pengelolaan yang merupakan suatu nilai penting dari kepuasan pelanggan (Danantyo \& Subagio, 2017). Selain kepuasan pelanggan, loyalitas pelanggan juga di pengaruhi oleh kepercayaan pelanggan, kepercayaan pelanggan adalah faktor pertama yang dipertimbangkan ketika membeli produk yang diinginkan (Soegoto, 2015). 


\section{Kesimpulan dan Saran Kesimpulan}

1. Variabel Nilai Pelanggan, Kepuasan Pelanggan, dan Kepercayaan ampu mempengaruhi Loyalitas Pelanggan pada Kedai Kopi Online di Kota Medan.

2. Nilai Pelanggan berpengaruh positif dan signifikan terhadap Loyalitas Pelanggan pada Kedai Kopi Online di Kota Medan.

3. Kepuasan Pelanggan berpengaruh positif dan signifikan terhadap Loyalitas Pelanggan pada Kedai Kopi Online di Kota Medan.

4. Kepercayaan berpengaruh positif dan signifikan terhadap Loyalitas Pelanggan pada Kedai Kopi Online di Kota Medan.

Dengan demikian, tingginya tingkat persaingan kedai kopi secara online, dari berbagai merek harus mampu menciptakan sesuatu yang berbeda terutama dari segi nilai pelanggan dengan membentuk nilai yang positif dan lebih kuat, kepuasan pelanggan dengan memberikan kepuasan yang melebihi harapan konsumen melalui inovasi-inovasi produk, kepercayaan terhadap merek dengan membangun integritas, reputasi merek, dan reputasi perusahaan yang lebih kuat.

\section{Saran}

1. Berdasarkan hasil penelitian dapat diketahui bahwasannya nilai pelanggan, kepuasan pelanggan, serta kepercayan berpengaruh positif dan signifikan terhadap loyalitas pelanggan, hal ini dapat dijelaskan dari hasil penelitian saat menyebarkan kuesioner kepada pelanggan kedai kopi online di kota Medan, namun dari hasil penelitian juga diperoleh masih ada pelanggan yang tidak merasakan nilai, kepuasan serta kepercayaan terhadap produk yang diberikan pihak kedai kopi online. Maka ada baiknya pihak kedai kopi online lebih memeperhatikan pelanggan dengan semakin berinovasi serta kreatif dalam memperluas produk kopi online seperti rasa, packaging, dan pelayanan.

2. Diharapkan penelitian berikutnya tidak sebatas variabel nilai pelanggan, kepuasan pelanggan dan kepecayaan tetapi juga menambahkan variabel lain pada penelitian selanjutnya dan perlunya ditambah faktor-faktor yang mempengaruhi loyalitas pelanggan. Hal ini betujuan untuk semakin menyempurnakan pemahaman terhadap faktor-faktor yang mempengaruhi loyalitas pelanggan.

\section{Daftar Pustaka}

Ammurabi, S. D. (2020). Siasat industri kopi bertahan di tengah pandemi. Alinea.id.

Danantyo, Y., \& Subagio, H. (2017). Pengaruh Service Quality Terhadap Customer Satisfaction dan Customer Loyalty pada Citra mitra Anugrah.

Dewi, A. (2017). PENGARUH KUALITAS PELAYANAN, KEPUASAN PELANGGAN TERHADAP LOYALITAS NASABAH BANK BRI DI SURAKARTA.

KatalogPromosi. (2020). Promo ngopi Dirumah.

Kotler, P., \& Keller, K. L. (2016). Marketing Management. England.

Laucereno, S. F. (2020). Cara Kedai Kopi Bertahan di Tengah Pandemi Corona. detikFinance. 
Logiawan, Y., \& Hartono. (2014). Aanalisa Customer Value terhadap Customer Loyalty dengan Customer Satisfaction Pada Restoran Bandar Jakarta.

Lovelock, C. H., \& Wirtz, J. (2018). Essentials of Service Marketing. London.

Pine, B. J., \& Gilmore, J. H. (2011). The Experience Economy : Work Is Theatre \& Every Business a Stage . Boston.

Pradika, H. (2019). Pertumbuhan Bisnis Kedai Kopi. Swa.co.id.

Pramita, D. (2015). Pengaruh Servicescape terhadap kepuasan dan dampakmua pada loyalitas Nasabah.

Salomon, M. (2006). Consumer Behavior Aeuropean Perspective. spain.

Saputra, H. S. (2012). Pengaruh Perceived Service Quality, Perceived Value, Satisfaction Dan image terhadap Customer Loyalty (Studi Kasus Garuda Indonesia).

Setiadi, D. (2016). Pengaruh Customer Satisfaction terhadap Customer Loyalty Dengan Mediasi Trust dan Commitment pada Konsumen Lazada .

Situmorang, S.H (2017). Riset Pemasaran. Medan

Soegoto, A. S. (2015). Persepsi Nilai Dan Kepercayaan Terhadap kepuasan dan dampaknya Terhadap Loyalitas Konsumen.

Sugiyono. (2017). Metodologi Penelitian Bisnis (Pendekatan Kuantitatif Kualitatif dan $R \&$ $D)$. Bandung: Alfabeta.

Sugiyono, P. D. (2019). Metode Penelitian \& Pengembangan. Bandung.

Tjiptono, F. (2018). Pemasaran Jasa. Jogjakarta.

weebly.com. (n.d.). perkembangan teknologi informasi. 